\title{
MENINGKATKAN MOTIVASI BELAJAR SISWA KELAS 9 MELALUI BIMBINGAN KELOMPOK DI SMP NEGERI 262 JAKARTA TIMUR
}

\author{
Anggraini \\ SMP Negeri 262 Jakarta Timur \\ anaanggraiani30@gmail.com
}

Received: 19 Juli 2020

Revised: 17 Agustus 2020

Accepted: 20 Agustus 2020

\begin{abstract}
Tujuan penelitian mengetahui motivasi belajar siswa kelas 9 melalui Bimbingan Kelompok Di SMP Negeri 262 Jakarta Timur. Tempat penelitian dilaksanakan pada Kelas 9 di SMP Negeri 262 Jakarta Timur dan waktu penelitian dilaksanakan selama 3 bulan dari Januari sampai dengan Maret 2019. Subjek kajian adalah siswa kelas 9 SMP Negeri 262 Jakarta Timur Tahun Pelajaran 2018-2019 yang berjumlah 12 siswa. Metode penelitian adalah penelitian tindakan bimbingan konseling. Peneliti menggunakan instrumen angket dan pedoman observasi. Hasil penelitian: 1. Pada Siklus pertama, jumlah siswa memiliki motivasi belajar sedang yaitu 5 siswa atau 41,7 \%, 5 siswa memiliki motivasi belajar rendah atau $41,7 \%$, dan 2 siswa memiliki motivasi belajar sangat rendah atau 16,6 persen. Dan $100 \%$ siswa masih memiliki skor motivasi belajar di bawah 70\%. 2. Pada siklus kedua, jumlah siswa memiliki motivasi belajar sangat tinggi yaitu 2 siswa atau 16,67\%, dan 10 siswa memiliki kategori motivasi belajar tinggi atau 83,33\% dan 100 persen siswa memiliki skor motivasi belajar di atas $70 \%$ yaitu dengan kategori tinggi. 3. Hasil penelitian ini dapat disimpulkan bahwa pelaksanaan bimbingan kelompok pada Siswa Kelas 9 Melalui Bimbingan Kelompok Di SMP Negeri 262 Jakarta Timur dapat mengefektifkan motivasi belajar menjadi semakin baik.
\end{abstract}

Keywords: Motivasi Belajar; Bimbingan Kelompok

(*) Corresponding Author:

Anggraini, anaanggraiani30@gmail.com

How to Cite: Anggraini. (2020). Meningkatkan Motivasi Belajar Siswa Kelas 9 Melalui Bimbingan Kelompok Di SMP Negeri 262 Jakarta Timur. Research and Development Journal of Education, 1(1), 1222.

\section{INTRODUCTION}

Masalah yang ada di kelas 9 SMPN 262 Jakarta Timur adalah ada siswa yang tidak suka dengan mata pelajaran tertentu karena guru belum mampu untuk menyajikan pembelajaran yang kreatif. Ada juga siswa yang belajar dengan kemauannya sendiri tetapi kemauan itu muncul ketika mereka sedang ingin belajar. Motivasi belajar siswa masih rendah karena guru belum maksimal dalam mengefektifkan motivasi belajar sehingga nilai siswa masih ada yang di bawah KKM. Salah satu guru yang bertugas untuk mengefektifkan peran motivasi belajar adalah guru BK karena guru BK memiliki kemampuan untuk mendekati siswa dengan pendekatan yang baik dan tepat. Guru bimbingan dan konseling/konselor memiliki tugas, tanggungjawab, untuk melayani bimbingan dan konseling kepada para siswa.

Tugas guru bimbingan dan konseling adalah mengembangkan diri para siswa sesuai kebutuhan, potensi, bakat, minat, dan kepribadian para siswa sehingga siswa akan berkembang dengan baik. Salah satu tugas guru BK adalah mengembangkan 
karir para siswa. Pengembangan karir yaitu pelayanan yang mengembangkan kemampuan siswa dalam pengambilan keputusan untuk memilih jurusan untuk kuliah. Di samping itu, guru BK memiliki peran untuk mengembangkan konsep diri yang positif pada siswa dan motivasi belajar.

Layanan membimbing siswa secara kelompok merupakan bantuan yang diberikan pada individu dalam suasana kelompok guna membantu mereka melihat faktor penyebab motivasi belajarnya yang rendah, kemudian melalui dinamika kelompok mencari dan memecahkan sebab timbul-nya menurunnya motif belajar siswa itu bersama anggota kelompok didalamnya, serta menumbuhkembangkan sikap untuk lebih termotivasi dalam belajar, melalui diskusi kelompok dan komunikasi multiarah antara pemimpin kelompok dengan anggota kelompok.

Berdasarkan uraian masalah, rumusan masalah yaitu bagaimana menaikkan motivasi belajar para siswa kelas 9 melalui bimbingan kelompok di SMP Negeri 262 Jakarta Timur?. Tujuan penelitian mengetahui motivasi belajar siswa kelas 9 melalui Bimbingan Kelompok Di SMP Negeri 262 Jakarta Timur.

\section{LITERATURE REVIEW}

\section{Motivasi Belajar}

Menurut Uno (2017: 23), motivasi belajar merupakan gerakan dari luar dan dalam peserta didik untuk merubah tingkah perilaku untuk berhasil, meraih cita-cita, penghargaan, dan mencapai masa depan yang gemilang. Winkel (2018: 160), menyatakan motivasi belajar merupakan keseluruhan energi pendorong kejiwaan dari dalam diri siswa yang menyebabkan siswa ingin belajar. Sardiman (2017: 75), menyatakan motivasi belajar merupakan segala kekuatan penggerak didalam diri pembelajar yang dapat menimbulkan kegiatan belajar yang memberikan kekuatan kepada siswa untuk belajar dengan tujuan yang jelas sehingga siswa akan berhasil dan memberikan manfaat bagi si pembelajar. Motivasi belajar berdasarkan pengertian para Ahli dapat didisimpulkan motivasi belajar merupakan gerakan dari dalam dan luar siswa untuk belajar dengan baik dan semangat demi meraih tujuan belajar yang telah dirancang sehingga hasil belajar dapat bermanfaat bagi siswa. Menurut Uno (2017: 27-29), peran penting motivasi belajar dan pembelajaran, yaitu: 1) Menentukan agar siswa semangat belajar. 2) Peran motivasi dalam membuat siswa untuk tertarik belajar. 3) Meningkatkan ketekunan siswa dalam belajar. Hamalik (2017:108), menyatakan fungsi motivasi itu meliputi: 1) Mendorong siswa untuk belajar dengan baik. 2) Motivasi memberikan petunjuk tujuan pembelajaran bagi siswa. 3) Motivasi berfungsi sebagai motor bagi siswa untuk melakukan proses pembelajaran yang terarah.

Dari pendapat beberapa ahli, bahwa dapat dikatakan peran dan fungsi motivasi belajar adalah sebagai alat untuk mendorong siswa agar dapat belajar dengan semangat dan baik sehingga tujuan pembelajarn dapat tercapai dengan baik. Ciri-ciri siswa yang menyandang dorongan untuk belajar menurut Sardiman (2017: 83), yaitu: 1) Tekun mengerjakan tugas belajar sampai selesai. 2) Pantang menyerah. 3) Minat belajar tinggi. 4) Mandiri. 5) Ingin selalu mendapatkan tugas yang baru. 6) mampu mempertahankan pendapatnya. 7) Percaya diri. 8) suka menyelesaikan pertanyaan yang sulit. Uno (2017: 23), menjelaskan bahwa ciri-ciri para siswa yang terdeteksi dapat mengaplikasikan motivasi belajar: 1) keinginan untuk berhasil. 2) kebutuhan dalam belajar. 3) memiliki cita-cita di masa depan. 4) ingin penghargaan dalam belajar. 5) ingin belajar dengan suasana menarik. 6) ingin suasana belajar kondusif. 


\section{Bimbingan Kelompok}

Prayitno (2018:178), Bimbingan kelompok adalah aktivitas oleh sekelompok orang dengan menggunakan dinamika kelompok. Kegiatan ini memberikan kesempatan kepada kelompok untuk saling menyapa dan berkomunikasi untuk mengemukakan pendapat, menanggapi, memberi nasehat, dan lain-lain; semua yang dibahas dalam kelompok bimbingan memiliki manfaat untuk peserta kelompok bimbingan. Menurut Sukardi, (2017:442), Bimbingan kelompok adalah kegiatan kelompok yang dilakukan dengan menyampaikan informasi untuk mengembangkan perilaku terpuji individu dan mengembangkan potensi peserta didik. Menurut Sukardi, (2017:48), Layanan bimbingan kelompok bertujuan untuk memberikan kesempatan kepada peserta kelompok bimbingan membicarakan bahan bimbingan dan pengetahuan dari guru BK sebagai bekal untuk menyelesaikan masalah baik di keluarga, masyarakat, dan Sekolah.

Peneliti menyimpulkan layanan bimbingan kelompok adalah alat pengembangan diri siswa untuk memberikan pendapat, mengkritisi, memberi saran, memperbaiki afektif, dan etika positif sehingga siswa dapat mengembangkan kemampuan komunikasi yang baik yang dimiliki dan mengembangkan kecerdasaan sosial demi manfaat bagi dirinya sendiri dan masyarakat. Menurut Prayitno (2017:78), Teknik-teknik bimbingan kelompok adalah sama dengan konseling perorangan.

Pada dasarnya tujuan dan proses pengembangan pribadi melalui pelayanan BK perorangan adalah sama. Berbeda pada proses interaksi antarpribadi yang lebih luas dalam dinamika kelompok pada bimbingan kelompok. Prayitno (2017:81), menyatakan penilaian terhadap layanan bimbingan kelompok adalah penilaian proses dengan tahapan sebagai berikut: 1. Mengamati peserta selama kegiatan bimbingan berlangsung. 2. Menyampaikan pemahaman siswa pada materi yang didiskusikan. 3 . Mengungkapkan kegunaan dan manfaat pelayanan anggota bimbingan dalam bimbingan. 4. Menyampaikan keinginan anggota kelompok tentang kegiatan lanjutan yang akan dilaksanakan. 5. Mengungkapkan keberhasilan layanan yang menarik dan kondusif.

\section{METHODS}

Penelitian tindakan bimbingan konseling atau PTBK adalah pendekatan yang digunakan oleh Peneliti. Sampel penelitian yaitu siswa kelas 9 di SMP 262 Jakarta Timur Tahun Pelajaran 2018-2019 yang berjumlah 12 siswa. Sumber data penelitian ini adalah 9 di SMP 262 Jakarta Timur Tahun Pelajaran 2018-2019, dan kolaborator yaitu teman sejawat di SMP 262 Jakarta Timur yaitu guru BK. Peneliti menggunakan teknik observasi, dan angket. Analisis data yang diajukan peneliti menggunakan analisis data deskriptif persentase.

\section{RESULTS \& DISCUSSION}

\section{Siklus 1}

\section{a. Perencanaan (Planning)}

Peneliti menetapkan kolaborator, membuat jadwal pelaksanaan kegiatan yang telah disepakati antara praktikan, observer, dan anggota 
kelompok, menetapkan fasilitas layanan bimbingan kelompok berupa kelengkapan administrasi yaitu daftar hadir, lembar evaluasi, serta satuan layanan, dan menyiapkan intrumen pengumpulan data

\section{b. Pelaksanaan (Action)}

\section{Pertemuan Pertama}

Pada awal pertemuan ini peneliti melaksanakan layanan bimbingan kelompok dengan topik tugas Semangat Belajar. Kegiatan layanan bimbingan kelompok ini diawali dengan ucapan salam dan sapaan kepada anggota kelompok dan dilanjutkan dengan menjelaskan pengertian, tuujuan, azas, serta manfaat layanan bimbingan kelompok. Pada pertemuan pertama perkenalan diri dan penjelasan aktivitas bimbingan kelompok. Selanjutnya, saling berdiskusi.

Pemimpin kelompok melakukan variasi dalam tahap peralihan dengan memberikan permainan "kenalkan aku". Permainan tersebut merupakan permainan memperkenalkan diri dan mengingat identitas berupa nama, alamat, serta hobi sehingga sangat sesuai digunakan sebagai permainan pada pertemuan pertama dalam perkenalan. Pemberian permainan tersebut bertujuan untuk memunculkan dinamika kelompok, agar anggota kelompok menunjukkan keakraban.

Dalam tahap kegiatan topik yang dibahas adalah "semangat belajar". Pemberian topik tersebut bertujuan untuk menumbuhkan kemauan belajar pada siswa serta mengetahui seberapa besar semangat belajar anggota kelompok dan cara menumbuhkannya. Selama kegiatan berlangsung anggota kelompok masih belum bisa mengikuti dengan baik, karena anggota kelompok belum memahami tentang proses layanan bimbingan kelompok dengan jelas.

Aktivitas pelayanan bimbingan kelompok pertama, dinamika kelompok belum tercipta dengan baik. Pemahaman anggota kelompok tentang topik yang dibahas juga dirasa masih kurang. Anggota kelompok merasa sangat tertarik melaksanakan diskusi kelompok diselanjutnya. Terakhir, penyampaian kesimpulan dan mengisi penilaian segera serta menginformasikan pelaksanaan kegiatan bimbingan kelompok berikutnya.

\section{Pertemuan Kedua}

Dinamika kelompok tercipta lebih baik dari sebelumnya namun dirasa masih kurang. Pemahaman anggota kelompok tentang topik yang dibahas juga dirasa lebih baik dari sebelumnya. Namun masih ada siswa yang malu dalam berpendapat. Anggota kelompok merasa sangat tertarik melaksanakan aktivitas selanjutnya.

Aktivitas terakhir, membuat kesimpulan dari kegiatan yang sudah dilaksanakan dan mengisi laiseg serta menginformasikan pelaksanaan kegiatan bimbingan kelompok lanjutan.

\section{c. Observasi (Observation)}

Pada tahap ini, peneliti melakukan pengamatan terhadap anggota kelompok selama proses layanan bimbingan kelompok secara keseluruhan. Adapun hasil pengamatan perkembangan motivasi belajar dapat dilihat dalam hasil pengamatan perkembangan tingkat motivasi belajar siswa Kelas 9 Melalui Bimbingan Kelompok Di SMPN 262 Jakarta Timur pada siklus 1. 
Tabel 1.

Hasil Pengamatan Siklus 1

\begin{tabular}{cll}
\hline No & \multicolumn{1}{c}{ Indikator } & Hasil yang dicapai \\
\hline 1 & Tekun menghadapi tugas & Belum maksimal \\
2 & Ulet menghadapi kesulitan & Belum maksimal \\
3 & Menunjukan Minat belajar & Belum maksimal \\
4 & Lebih senang bekerja mandiri & Belum maksimal \\
5 & Cepat bosan pada tugas- tugas rutin & Belum maksimal \\
6 & Dapat mempertahankan pendapatnya & Belum maksimal \\
7 & Memiliki keyakinan & Belum maksimal \\
8 & Suka mengerjakan pertanyaan yang sukar & Belum maksimal \\
\hline
\end{tabular}

Sumber: Peneliti (2019)

Berdasarkan tabel.1, pengamatan proses dan hasil layanan bimbingan kelompok berjalan dengan baik dan sesuai dengan prosedur yang telah direncanakan pada awal pertemuan. Sebagian anggota kelompok mengalami peningkatan pada indikator.

Sedangkan berdasarkan hasil skala motivasi belajar dapat ketahui hasil layanan bimbingan kelompok setelah siklus 1. Adapun hasil penghitungan penyebaran angket pada siklus 1 dapat dilihat pada tabel berikut:

Tabel 2.

Hasil Penghitungan Penyebaran Angket Pada Siklus 1

\begin{tabular}{cccc}
\hline No & Nilai Total & Persentase & Kategori \\
\hline 1 & 6 & 4 & Rendah \\
2 & 8 & 5 & Rendah \\
3 & 6 & 4 & Sedang \\
4 & 6 & 4 & Sedang \\
5 & 8 & 2 & Rendah \\
6 & 3 & 5 & Sedang \\
7 & 3 & 5 & Sedang \\
8 & 2 & 5 & Sedang \\
9 & 0 & 7 & Rendah \\
10 & 2 & 5 & Sangat Rendah \\
11 & 4 & 9 & Rendah \\
12 & 4 & 6 & Sangat Rendah \\
\hline
\end{tabular}

Sumber: Peneliti (2019) 
Tabel 3.

Persentase Motivasi Belajar Pada Siklus 1

\begin{tabular}{ccc}
\hline Interval Persentase & Frekuensi & Kriteria \\
\hline $84 \% \leq \% \leq 100 \%$ & - & Sangat tinggi \\
$68 \% \leq \% \leq 84 \%$ & - & Tinggi \\
$52 \% \leq \% \leq 68 \%$ & 5 & Sedang \\
$36 \% \leq \% \leq 52 \%$ & 5 & Rendah \\
$20 \% \leq \% \leq 36 \%$ & 2 & Sangat rendah \\
\hline
\end{tabular}

Sumber: Peneliti 2019

Berdasarkan tabel di atas, nilai sedang yaitu berjumlah 5 siswa atau 41,7 persen, 5 siswa memiliki motivasi belajar rendah atau 41,7 persen, dan 2 siswa memiliki motivasi belajar sangat rendah atau 16,6 persen.

Hasil analisis deskriptif persentase siswa untuk melihat tingkat hasil persentase, yaitu sebagai berikut:

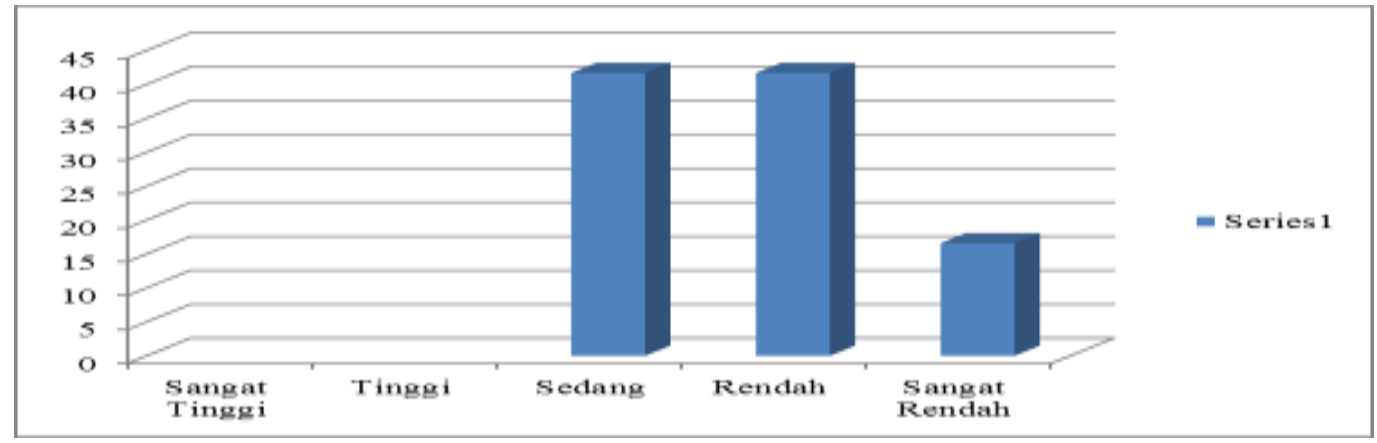

Sumber: Peneliti 2019

Gambar.1.

Bagan Peningkatan Motivasi Belajar Siklus 1

\section{d. Refleksi (Reflection)}

Evaluasi terhadap keseluruhan pelaksanaan proses pemberian layanan bimbingan kelompok. Beberapa evaluasi yang dilakukan peneliti berupa:

1. Evaluasi Proses

Pada siklus 1 ini peneliti menemui beberapa hambatan yaitu : a. Masih ada siswa yang kurang aktif dan malu-malu dalam mengemukakan pendapat. b. Di awal proses layanan bimbingan kelompok, anggota kelompok masih nampak canggung dan belum leluasa untuk berpendapat karena anggota kelompok belum paham tentang konsep layanan bimbingan kelompok. Pada pertemuan berikutnya peneliti terus membina hubungan baik dan menyampaikan kembali tentang konsep layanan bimbingan kelompok sehingga anggota kelompok mulai terbiasa dan leluasa dalam berpendapat. c. Waktu yang kurang strategis, karena layanan bimbingan kelompok dilakukan pada saat jam kegiatan belajar mengajar.

2. Evaluasi Hasil

Pemberian tindakan berupa kegiatan layanan bimbingan kelompok ternyata dapat meningkatkan motivasi belajar pada siswa. Setelah pemberian layanan bimbingan kelompok terjadi perubahan perilaku siswa dan perubahan 
tingkat motivasi belajar berdasar skala motivasi belajar,tetapi perubahannya belum signifikan karena 100 persen siswa masih memiliki nilai motivasi belajar di bawah $70 \%$.

\section{Siklus 2}

Hasil perbaikan pelaksanaan tindakan pada siklus 2 dilaksanakan dalam 4 tahap yaitu tahap perencanaan, tindakan, pengamatan, dan refleksi.

\section{a. Perencanaan (Planning)}

Sebelum memulai tindakan pada siklus 2 , peneliti terlebih dahulu membuat perencanaan. Persiapannya yaitu:

1. Menyiapkan Satuan Layanan (SATLAN). Menyiapkan metode ceramah dan diskusi, Menyiapkan materi layanan yaitu Tips, Meningkatkan Motivasi Belajar Menyiapkan kelengkapan administrasi berupa alat tulis, daftar bimbingan kelompok, laiseg, Menyiapkan alat bantu dokumentasi.

2. Menyiapkan Satuan Layanan (SATLAN) Menyiapkan metode ceramah dan diskusi, Menyiapkan materi layanan yaitu determinan motivasi belajar terhadap prestasi akademik, Menyiapkan kelengkapan administrasi berupa alat tulis, daftar bimbingan kelompok, laiseg Menyiapkan alat bantu dokumentasi.

\section{b. Pelaksanaan (Action)}

Pada tahap tindakan ini, peneliti melaksanakan aktiivtas sesuai dengan tahapan layanan bimbingan kelompok. Tahap tindakan pada siklus 2 ini dilaksanakan sebanyak dua kali pertemuan. Masing-masing pertemuan dilakukan satu kali layanan bimbingan kelompok topik tugas. Secara lebih rinci dijelaskan sebagai berikut:

\section{Pertemuan Pertama}

Menjelaskan sekilas tentang hakikat, maksud, dan penggunaan layanan bimbingan kelompok. Hal ini dilakukan dengan maksud agar mengerti yang dibahas. Kemudian pemimpin kelompok memberikan permainan lingkaran berbelit. Dalam permainan ini anggota kelompok membentuk lingkaran dan ada yang berdiri di tengah. Kemudian,siswa saling bergandengan tangan. Tujuannya untuk mengembangkan sikap kerjasama. Pada tahap peralihan, anggota kelompok sangat antusias dan siap untuk melanjutkan ke tahap kegiatan. Pada tahap kegiatan, topik yang dibahas yaitu tips meningkatkan motivasi belajar. Tujuan dari pembahasan topik ini yaitu siswa mampu belajar dengan keras dating dari dalam dirinya. Pada kegiatan ini pemimpin kelompok menanyakan kepada anggota kelompok tentang motivasi belajar. Anggota kelompok terlihat antusias dan aktif dalam berpendapat.

Aktivitas penutup menanyakan pada anggota. kelompok apa yang telah diperoleh dari pelaksanaan aktivitas yang dilaksanakan. Selanjutnya memberikan kesimpulantentang cara meningkatkan motivasi belajar. Pada proses aktivitas bimbingan pada pertemuan ini, dinamika kelompok sudah nampak dengan sangat baik. Semua anggota kelompok sudah aktif untuk berpendapat. Pemahaman anggota kelompok mengenai sikap toleransi sudah baik. Dinamika kelompok sudah nampak dengan sangat baik. Antusias anggota kelompok sangat tinggi, terlihat dari berbagai pendapat yang 
bervariasi. Selama tahap kegiatan anggota kelompok mampu bertukar pendapat dengan baik dan memberikan tanggapan secara positif.

\section{Pertemuan Kedua}

Pemimpin kelompok memberikan permainan mutiara dalam guci. Dalam permainan ini pemimpin kelompok menggambar sebuah guci dimana guci tersebut berisi batu, kerikil, pasir, dan terdapat satu mutiara. Anggota kelompok mendiskusikan bagaimana cara mengeluarkan mutiara tersebut. Hal ini bertujuan untuk melatih kerjasama dan keberanian siswa dalam berpendapat.

Pada tahap kegiatan, topik yang dibahas yaitu kontribusi motivasi belajar terhadap peningkatan prestasi akademik peserta didik. Pada kegiatan ini pemimpin kelompok menanyakan kepada anggota kelompok tentang pengertian motivasi belajar dan pengertian prestasi. Anggota kelompok terlihat sangat antusias serta terlihat semua anggota kelompok aktif dan mampu berpendapat.

Kegiatan berikutnya tanya jawab antara anggota kelompok bimbingan. Pada proses kegiatan ini dinamika kelompok sudah nampak dengan sangat baik. Semua anggota kelompok sudah aktif untuk berpendapat. Suasana mulai terkondisi dan perhatian anggota kelompok terpusat pada kegiatan bimbingan kelompok. Pemahaman anggota kelompok mengenai sikap toleransi sudah baik. Pada pertemuan terakhir aktivitas pelayanan bimbingan kelompok pada siswa dan masalah dinamika kelompok sudah nampak dengan sangat baik. Antusias anggota kelompok sangat tinggi, terlihat dari berbagai anggota kelompok yang berebut untuk mengemukakan pendapat. Setelah kegiatan bimbingan kelompok diakhiri, peneliti mengisi angket motivasi belajar setelah dilaksanakannya siklus 2 .

\section{c. Observasi (Observation)}

Hasil pengamatan perkembangan motivasi belajar dapat dilihat dalam hasil pengamatan perkembangan tingkat motivasi belajar siswa Kelas 9 Melalui Bimbingan Kelompok Di SMPN 262 Jakarta Timur pada siklus 2.

Tabel 4.

Hasil Pengamatan Siklus 2

\begin{tabular}{clc}
\hline No & \multicolumn{1}{c}{ Indikator } & Hasil yang dicapai \\
\hline 1 & Tekun menghadapi tugas & Sudah maksimal \\
2 & Ulet menghadapi kesulitan & Sudah maksimal \\
3 & Menunjukan Minat belajar & Sudah maksimal \\
4 & Lebih senang bekerja mandiri & Sudah maksimal \\
5 & Cepat bosan pada tugas- tugas rutin & Sudah maksimal \\
6 & Dapat mempertahankan pendapatnya & Sudah maksimal \\
7 & Memiliki keyakinan & Sudah maksimal \\
\hline
\end{tabular}




\begin{tabular}{ll}
\hline $8 \quad$ Suka mengerjakan pertanyaan yang sukar & Sudah maksimal \\
\hline Sumber : Peneliti 2019
\end{tabular}

Sedangkan berdasarkan hasil skala motivasi belajar dapat ketahui hasil layanan bimbingan kelompok. Adapun hasil penghitungan pada skala motivasi belajar setelah mengikuti layanan bimbingan kelompok pada siklus 2 dapat dilihat pada tabel berikut:

\section{Tabel 5.}

Hasil Penghitungan Penyebaran Angket Pada Siklus 2

\begin{tabular}{cccc}
\hline No & Nilai Total & Persentase & Kategori \\
\hline 1 & 10 & 3 & Tinggi \\
2 & 14 & 6 & Tinggi \\
3 & 05 & 0 & Tinggi \\
4 & 14 & 6 & Tinggi \\
5 & 12 & 5 & Tinggi \\
6 & 110 & 3 & Tinggi \\
7 & 09 & 3 & Tinggi \\
8 & 25 & 3 & Tinggi \\
9 & 26 & 4 & Tinggi \\
10 & 23 & 2 & Tinggi \\
11 & 30 & 7 & Sangat Tinggi \\
12 & 36 & 1 & Sangat Tinggi \\
\hline
\end{tabular}

Sumber: Peneliti 2019

Tabel 6.

Presentase Motivasi Belajar Pada Siklus 2

\begin{tabular}{ccc}
\hline Interval Persentase & Frekuensi & Kriteria \\
\hline $84 \% \leq \% \leq 100 \%$ & 2 & Sangat tinggi \\
$68 \% \leq \% \leq 84 \%$ & 10 & Tinggi \\
$52 \% \leq \% \leq 68 \%$ & & Sedang \\
$36 \% \leq \% \leq 52 \%$ & & Rendah \\
$20 \% \leq \% \leq 36 \%$ & & Sangat rendah \\
\hline
\end{tabular}

Sumber: Peneliti 2019

Jumlah siswa memiliki motivasi belajar sangat tinggi berjumlah 2 siswa atau 16,67 persen, dan 10 siswa memiliki nilai tinggi atau 83,33 persen. Hasil analisis deskriptif persentase siswa dapat dilihat di bawah ini: 


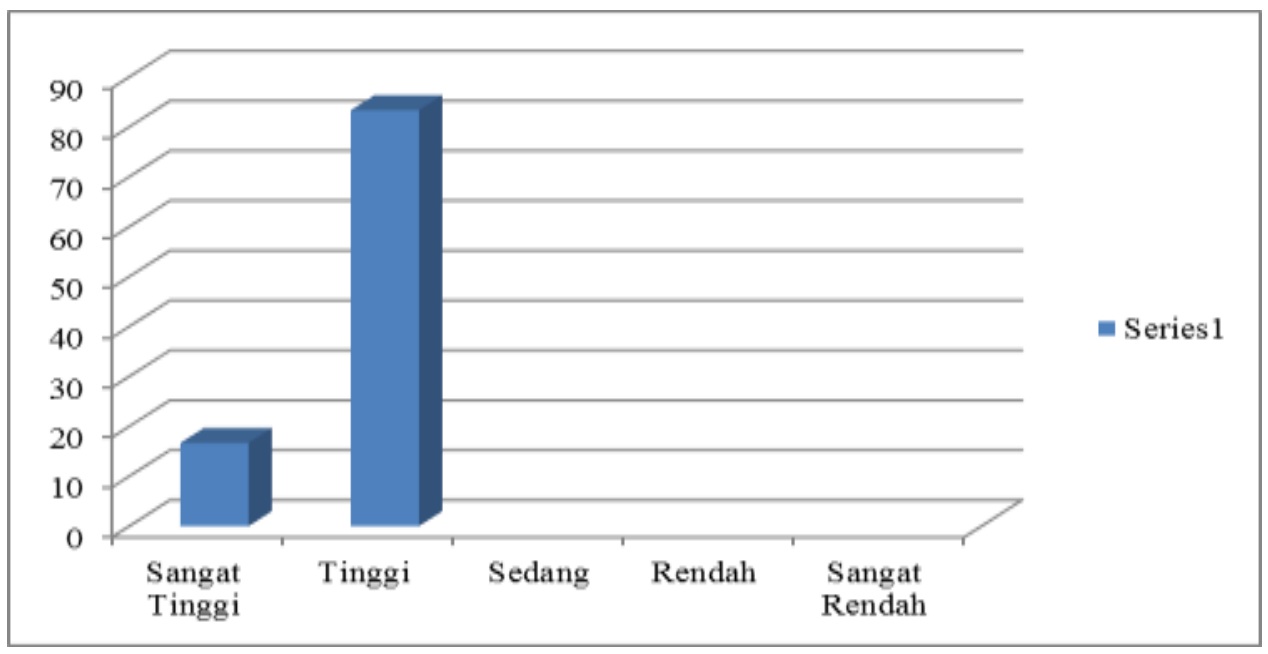

Sumber: Peneliti 2019

Gambar 2.

Bagan Peningkatan Motivasi Belajar Siklus 2

\section{d. Refleksi (Reflection)}

Refleksi yang harus dikembangkan adalah guru BK harus mengembangkan pelayanan bimbingan kreatif dan inovatif dalam mengembangkan dan menambahkan motivasi belajar siswa agar lebih baikyaitu dengan menggunakan media pembelajaran dan metode pembelajaran yang lebih kreatif dan inovatif.

\section{CONCLUSION}

berikut:

Berdasarkan deskripsi dan pembahasan penelitian maka simpulan sebagai

1. Pada Siklus pertama nilai sedang berjumlah 5 siswa atau $41,7 \%, 5$ siswa memiliki motivasi belajar rendah atau $41,7 \%$, dan 2 siswa memiliki nilai sangat rendah atau 16,6 persen. Dan $100 \%$ siswa masih memiliki skor motivasi belajar di bawah $70 \%$.

2. Pada siklus kedua nilai sangat tinggi yaitu berjumlah 2 siswa atau $16,67 \%$, dan 10 siswa memiliki motivasi belajar tinggi atau $83,33 \%$ dan 100 persen siswa memiliki skor motivasi belajar di atas $70 \%$ yaitu dengan kategori tinggi.

3. Hasil penelitian ini dapat disimpulkan bahwa pelaksanaan bimbingan kelompok pada Siswa Kelas 9 Melalui Bimbingan Kelompok di SMP Negeri 262 Jakarta Timur Tahun Pelajaran 2018-2019 dapat mengefektifkan motivasi belajar menjadi semakin baik.

\section{REFERENCES}

Hamalik, Oemar. (2017). Proses Belajar Mengajar. Jakarta. PT Bumi Aksara.

Prayitno. (2018). Jenis Layanan Dan Kegiatan Pendukung. Padang: FIP UNP.

Sardiman, A. M. (2017). Interaksi dan Motivasi Belajar Mengajar. Jakarta : PT Raja Grafindo.

Sukardi, Dewa Ketut. (2017). Pengantar Pelaksanaan Program Bimbingan dan Konseling di Sekolah. Jakarta : Rineka Cipta. 
Uno, Hamzah B. (2017). Teori motivasi dan Pengukurannya. Edisi Pertama. Cet. Ke-8. Jakarta: Bumi Aksara.

Winkel, W. S. (2018). Psikologi Pendidikan dan Evaluasi Belajar. Jakarta: PT. Gramedia Pustaka Utama. 